\title{
Too Little, Too Late \\ The Constraining Effect of Traditional Peacekeeping Norms On the UN Protection Forces and its Consequences
}

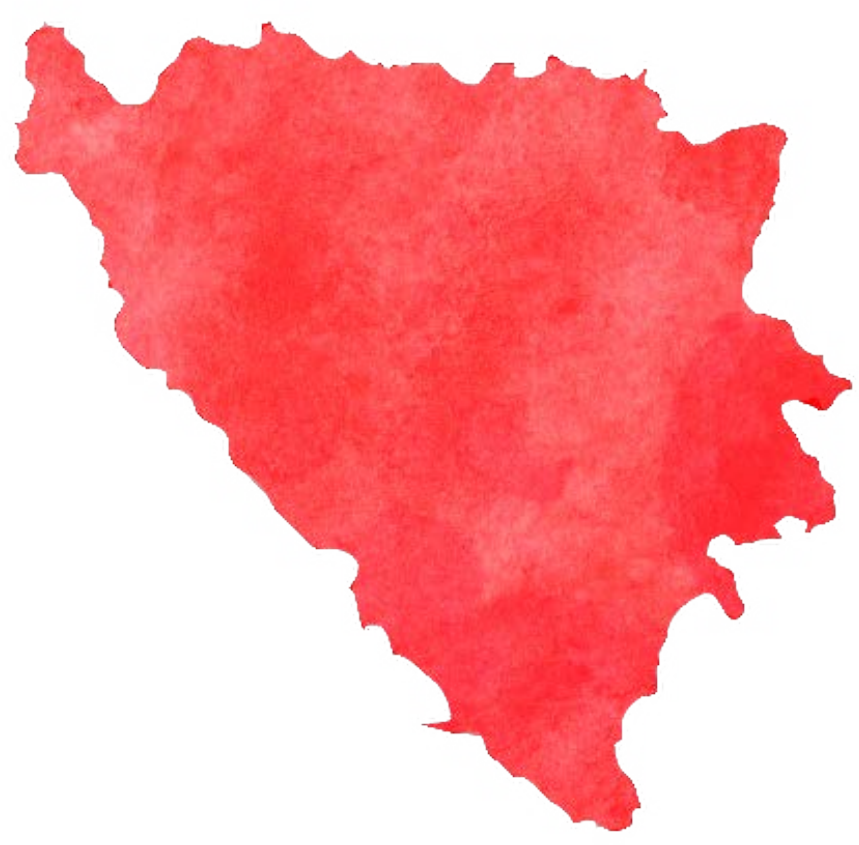

Avery Franken

edited by Ewa Niżałowska and Maëna Raoux $\mathrm{POL} / 360$ War and Peace 


\section{Abstract}

$\mathrm{D}$ uring the Bosnian War (1992-1995), despite the efforts of the United Nations Protection Force (UNPROFOR), thousands of lives were lost in heinous attacks on Bosnian Muslims, perpetrated mostly by Bosnian Serbs. Using a constructivist approach, this paper investigates why the United Nations (UN) failed in their mandate to protect the Bosnian people. To do so, it examines the deeply entrenched norms that have traditionally guided UN peacekeeping namely, impartiality and non-use of force. By tracing the key events that defined the UN's involvement in this conflict in relation to existing theoretical models of norm emergence and evolution, the paper finds that the UN's strict adherence to these principles significantly contributed to their failure to achieve their objectives. This is evidenced by the limited capacity of the UN peacekeepers during the conflict, the swift improvement of conditions following the replacement of UNPROFOR with the NATO-led Implementation Force, and the developments within the UN that ensued in the following years. The paper concludes with potential implications of these findings and suggestions for further research.

\section{Introduction}

$\mathrm{B}$ etween 11-22 July 1995, more than 7000 Bosnian citizens were murdered-and thousands more attacked, tortured and sexually assaulted-under the so-called protection of the United Nations (UN) in Srebrenica, Bosnia (Daalder 2016). The Srebrenica Massacre, also known as the Srebrenica Genocide, was perpetrated by the Bosnian Serbs against Bosnian Muslims as part of a brutal campaign of ethnic cleansing during the Bosnian War. The UN's ongoing failure to protect the Bosnian civilians as mandated became shockingly clear in this attack, both to the major state actors involved and to the world at large, and so triggered a quick change of course that ended the Serb violence and accelerated peace talks within the year (Kaufman 1999, 1).

Using a constructivist approach, I will seek to address why the UN's peacekeeping efforts in Bosnia failed by tracking the institutional norms that shaped its mandate, and by analyzing how the institution reckoned with its failure in the time following the conflict. More precisely, I propose that the UN's attempts at peacekeeping in Bosnia from 1992 to 1995 via the UN Protection Force (UNPROFOR) failed due to their rigid adherence to the traditional peacekeeping norms of impartiality and nonuse of force. The discrepancy between the UN's mandate and the needs 
on the ground resulted in gravely inadequate peacekeeping operations, the removal of the UN from Bosnia, and a consequent reckoning within the institution. To illustrate this argument, I start with a brief historical overview of the Bosnian war and a review of the existing literature on constructivist approaches to peacekeeping and the role of international norms therein. I will also highlight key alternative explanations for the inadequacy of the UN's efforts in Bosnia. Next, I apply the theoretical framework of norm change developed in the first section to the series of events in the Bosnian War: the ill-fated UN mission, the removal of the UN and the conclusion of the conflict, and finally, the normative restructuring within the UN in the years that followed. I conclude with a review of the argument, potential implications for contemporary peacekeeping efforts, and suggestions for further research.

\section{The Bosnian War: An Overview}

It is generally understood that the main factors leading to the dissolution of Yugoslavia in the 1990s were the death of Josip Broz Tito in 1980, the ensuing economic depression, and the instability that followed the end of the Cold War in 1991 (Kaufman 1999, 1). Following Tito's death and in response to threats posed by economic uncertainty and the shifting global order, nationalist leaders rose to power in Croatia, Serbia, and Bosnia and Herzegovina. Kaufman states in her review of the conflict that, "rather than loyalty to the country of Yugoslavia, growing nationalist feelings led to ethnic loyalties instead" (1). In Bosnia, the result of this division was the emergence of armed conflict between Bosnian Muslims and Bosnian Serbs when, closely following the model seen in the Croatian War (1991-1995), the Serbs declared their autonomy in January 1992 and stationed armed forces throughout the country (2).

The Bosnian War had started. What followed was a period of inaction on the part of the international community. As the great powers hesitated to intervene, the Serbs became increasingly brutal in their attacks on non-Serbs, and in particular on the Muslim community. Eventually, the acts of genocide engendered international condemnation that was too strong for the great powers to ignore. By late 1992, the UN Protection Force (UNPROFOR) was deployed in Bosnia, with limited military support from the North Atlantic Treaty Organization (NATO). These forces proved to be wholly ineffective in stopping the violence and, after three years of increasingly severe humanitarian crises, which will be further detailed below, they were decommissioned and replaced by NATO's Implementation Force (IFOR) under the Dayton Agreement in January 1995 (3-4). 


\section{A Normative Approach to Peacekeeping}

A strong body of research exists concerning the role that norms play in shaping the actions of international institutions, which will be used to inform and structure the proceeding analysis. Most importantly, Marion Laurence's definition of norms - "collective expectations for the proper behaviour of actors with a given identity" - is succinct, and will be referenced throughout (Laurence 2018, 2). Laurence details the UN's deep-seated commitment to the principles of impartiality and non-use of military force, identifying these principles' preeminence in the UN's given identity as a non-partisan supporter of peace as its cause (2). Similarly, Emily Rhoads identifies these two norms as interrelated principles that form the "bedrock of peacekeeping" (Rhoads 2016, 47). She summarizes impartiality by simply stating "that peacekeepers should be informed and unbiased when making decisions and taking action" and notes that the use of force in any capacity other than selfdefense risks undermining said neutrality (25). Peacekeeping, in this traditional sense, is generally summarized as efforts taken after a ceasefire but before an official settlement to ensure that relations on the ground remain conducive to a resolution (Bellamy \& Williams 2004, 3).

To analyze the reshaping of these norms after UNPROFOR, I will employ elements of the following models. First, Widmaier and Glanville argue that a certain level of ambiguity in international norms-one that is sufficient to allow the norm to be interpreted in multiple ways and applied to novel circumstances-extends the lifecycle of the norm, while allowing gradual reform (Widmaier \& Glanville 2015, 379). Furthermore, they argue that adhering to established norms too rigidly "may be seen as an inefficient use of information which may lead to strategically irrational choices" (379). This leads directly to a second model proposed by Martha Finnemore and Kathryn Sikkink, in which norm entrepreneurs-prominent individuals with access to influential platforms-identify existing issues and construct new standards of appropriateness to shift the norms in favour of their conceptions (Finnemore \& Sikkink 1998, 896-897).

In an amalgamation of the elements outlined above, I seek to delineate the process by which the UN, strictly adhering to its core principles of traditional peacekeeping, was too rigid in its application of its peacekeeping doctrine, and therefore failed to match the complexity of the situation with a similar level of nuance in its own approach. While I argue that the norms of the institution are the driving force of this inadequacy, a widely held view is that it was the inability of the great powers to converge on a more robust common strategy that led to the 
ill-fated mandate of UNPROFOR. Barry H. Steiner argues that the major states involved (mainly the United States, Britain, France, Germany, and Russia) had varying interests in the conflict, and thus held contradictory beliefs as to whom to support and the extent to which they should involve themselves (Steiner 2004, 82-83). He asserts that the deadlock borne from these divides was the reason for the UN's impotence, insofar as it "undercut the chances of punitive action ... and it permitted the primary antagonists to persist in aiming at a one-sided solution" (Date, 83). I do not deny that these differences contributed to the inefficacy of the UN's mandate in Bosnia. However, I posit that the contradictory state interests are not sufficient in and of themselves to fully explain it. The deficiency of the established norms in the face of the complexity of postCold War era civil conflict exacerbated the damage caused by diverging state interests. It served as a 'lowest common denominator' default which, when so strictly interpreted by the UN, was not only insufficient, but detrimental to the safety of the Bosnian people. As will be discussed below, the efforts at reform made by the UN following the conflict serve as evidence for the UN's own responsibility in this matter.

\section{Case Study: Peacekeeping Norms and UNPROFOR}

The proceeding case study of the Bosnian war will be divided into two main sections: firstly, the implementation of the UNPROFOR mandate, the Srebrenica Crisis, and the removal of the UN from Bosnia; and secondly, the evidence of intentional norm change within the UN following the conflict.

\section{The Application of Peacekeeping Norms Under UNPROFOR}

In late 1992, when UNPROFOR was deployed, war had been proceeding in Bosnia for almost a year, and the capital city, Sarajevo, was under ongoing siege from the Bosnian Serbs (Kaufman 1999, 3-4). This war was exemplary of a well-documented shift in the nature of conflict occurring at the time. With the end of the Cold War, intra-state conflicts rose between non-state actors who were prone to non-conventional military strategies of guerrilla warfare and civilian targeting, and who, in their illegitimacy, were not opposed to exploiting agreements made by larger institutions (Holsti 1996). The UNPROFOR mandate primarily protected aid convoys and other humanitarian work being carried out by the UN High Commission for Refugees (UNHCR) (Kaufman 1999, 3-4). However, the tangible implementation of these agreements was so heavily constrained by the norms of impartiality and non-use of force 
that this overall goal of protection was virtually impossible to achieve following the shift to more insidious warfare.

Firstly, the norm of impartiality guided the UN to impose a weapons embargo equally on both the Bosnian government and the Yugoslavbacked Bosnian Serbs (Fetherston, Ramsbotham, \& Woodhouse 1994, 194). This embargo obstructed the Bosnian government's ability to protect itself from the more violent Serbs and made securing the safety of Bosnian civilians much more challenging. It also contributed to the discordance between the major states, as the US strongly opposed the blanket application of the weapons embargo, and so unilaterally provided arms to the Bosnian government (Steiner 2004, 82-83).

Secondly, the norm of non-use of force restrained the UN troops from using force in any case other than self-defense, which made their presence essentially inconsequential in the conflict. The Serbs knew that the UN could not use force against them, and that any attempt at deterrence was thus not credible. Thus, they regularly ignored proposed truces and assaulted UN troops, even using them as human shields and kidnapping them (Steiner 2004, 82). The most acute display of this inimical discrepancy between the needs of the situation and what UNPROFOR offered was the UN's formation of eight "safe zones" for Bosnian Muslims throughout the state, in which, supposedly, Muslims would be able to gather safely. Unsurprisingly, the UN troops were only allowed to protect themselves, and so these "safe zones" were attacked and invaded multiple times. The ethnic cleansing in Srebrenica occurred because the Bosnian Serbs understood the limitations of the UN response, and therefore perceived the costs of attacking to be much lower than the benefits (Steiner 2004, 82-83). These failures show that the UN adhered to institutional norms of impartiality and non-use of force in an era where the nature of conflict was changing in such a way that these principles bore no workable strategies of peacekeeping. As predicted by Widmaier and Glanville's theory on the benefits of norm ambiguity, the UN's inability to adapt such thoroughly indoctrinated norms of practice to novel circumstances is what ultimately led to its irrational-or at least, thoroughly unproductive-decisions in Bosnia and, furthermore, its removal from the situation following the Srebrenica Massacre (Widmaier \& Glanville 2015, 379).

Counter to the Bosnian Serbs' expectations, the brutal attack on Srebrenica was indeed enough to force the Western international players into action: NATO was almost immediately given previously-denied authority to lead an air campaign over the main Serb-controlled areas (Kaufman 1999, 4). According to Kaufman, this use of military force 
sufficiently raised the costs of continuing for both parties, and finally created circumstances in which negotiations were somewhat likely to take place and be adhered to. By this point, the responsibility of handling the conflict was passed over from the UN to NATO, as there was a widespread consensus that direct and credible threat of force would be necessary for any future peace proposal to succeed.

To that end, the Dayton Agreement, developed in the fall of 1995 by American, European, Bosnian, and Serb representatives, was fairly similar in content to previous agreements, except for two key differences: first, its directives targeted the Bosnian Serbs specifically and favoured the legitimate Bosnian government by giving it 51 percent of the post-war landscape; and second, it would be militarily enforced by the NATO-led Implementation Force (IFOR). The transition from the now decommissioned UNPROFOR to IFOR was smooth, and the implementation of Dayton was widely seen as a success (Kaufman 1999, 4). Ivo H. Daalder notes that, "the problem that had stymied NATO decision-makers for so long-the vulnerability of UNPROFOR troopswas resolved with relative ease. In December 1995, when implementation of Dayton began, most of the UNPROFOR troops changed helmets and were instantly transformed into IFOR [Implementation Force] soldiers" (Daalder 2016). In this way, another international organization, largely composed of the same decision-making actors with similarly incongruous interests, but whose identity was not so closely tied to notions of neutrality, was able manage the exact issues that had plagued the UN. This serves as evidence that it was the normative limitations on the UN's abilities, not its constituent state actors, that impeded its success in Bosnia.

\section{Changes in UN Peacekeeping Norms Post- UNPROFOR}

Similarly, one could claim that the peacekeeping failure in Bosnia was the result of insufficient inter-institutional delegation, not factors internal to the UN itself. The under-involvement of NATO, which had already institutionalized the use of force as a viable strategy in peace operations, could be cited as a broader cause of the failure, rather than the UN's normative limitations. While NATO resources were certainly underused in this situation, this argument (and the state-centric view that Steiner proposes, detailed above) can be countered by the second section of this case study, which details the internal developments made by the UN following its ineffective efforts. The UN reconciled with its failure by making a variety of efforts to change its norms of impartiality 
and the use of force, which indicates that there were indeed decisive flaws within the institution that key individuals felt needed to be resolved for the future. This is evidenced by three closely related actions taken by the UN in the late 1990s and early 2000s, all of which embody the theories of evolving international norms mentioned previously. These are: its formal apology for the failure of its efforts in Bosnia, its increasingly broad scope of interpretation of traditional peacekeeping norms, and its rhetorical shift to new framing devices to justify the new rights of UN troops.

Firstly, it is abundantly clear that the UN itself took issue with its own reliance on norms of neutrality in the Secretary General's Report issued on November 16, 1999. An introduction by a high-ranking UN official plainly states that, “... we failed to do our part to save the people of Srebrenica from the Serb campaign of mass murder [...] these failings were in part rooted in a philosophy of neutrality and nonviolence wholly unsuited to the conflict in Bosnia" (Crossette 1999). This is a fitting example of what Finnemore and Sikkink identify as part of the first phase in the evolution of a norm: "norm emergence," when norm entrepreneurs, who have the societal power and platforms necessary to advocate for particular reforms, identify problems within the existing system (Finnemore \& Sikkink 1998, 896-897). Aptly following this model, the Secretary General of the UN, Kofi Annan, directly cited traditional UN norms as a key issue with past peacekeeping efforts and set the tone for upcoming adjustments.

Secondly, since the emergence of intra-state conflict as a main arena for peacekeeping efforts in the 1990s, the UN has expanded the interpretive flexibility of its core tenets (Laurence 2018, 2). These principles are integral to the UN's identity, and so it has not abandoned the rhetoric of neutrality in its statements and missions; however, according to Laurence, "references to impartiality persist but ways of being 'impartial' have proliferated" (Laurence 2018, 7). In its new form, impartiality permits the use of force and disparate treatment of warring sides if it is in pursuit of "ostensibly universal goals, such as human rights" (9). This increased flexibility of interpretation of traditional terms is evidence that the UN expanded its ideas of appropriateness and attempted to diffuse this shift via its actions internationally. This is another emblematic practice in the pursuit of norm change, according to Finnemore and Sikkink, and works in tandem with the third and final redirection seen in UN norms and practices following the Bosnian war (Finnemore \& Sikkink 1998, 897).

Perhaps in what seems to be a contradiction to the preceding point, 
the UN and its member states have also promoted new names to account for these ideational shifts. I would argue that one pattern does not in fact preclude the other, and what can be seen here is simply two methods being employed in pursuit of the same end. That said, to justify the expanded repertoire of acceptable peacekeeping operations, the UN introduced new terms and systems of ideas-what Finnemore and Sikkink refer to as "frames" (1998, 897)-including broadly applicable concepts of human security and the responsibility to protect (Lawrence 2018, 7). Both frames seek to place the goal of protecting human life at the top of the institution's hierarchy of priorities: an "ostensibly universal goal," as cited above (7). It implies that it is justifiable to pursue this goal with whatever means necessary, or at least with an increasingly larger set of means that includes expanded use of force and incongruent treatment of opposing parties.

To conclude this section, the norms of impartiality and non-use of force in their traditional senses proved largely insufficient in Bosnia. In response, the UN made an explicit effort, starting in the years following the war, to adjust its normative structures in such a way that UN forces would have more rights and competencies with which to face similarly challenging situations in the future. These actions are well-documented in the literature as methods of intentional norm changes, and so very strongly support the argument that the pre-existing peacekeeping norms of the UN forces were responsible for the failure of UNPROFOR's mandate in Bosnia.

\section{Conclusion}

In review, the norms of impartiality and non-use of force are deeply entrenched in the UN's identity as a peacekeeper in conflict scenarios. However, in the face of the non-conventional military tactics during the Bosnian war, they proved ineffective, constricting the efforts of UNPROFOR and resulting in the tragic massacre of unprotected Bosnian Muslims and other non-Serbs, a stalemate in the peace process until its replacement by NATO, and a period of crafted norm evolution within the UN, which was intended to adapt the original norms to the modern realities of war and increase the efficacy of UN peacekeeping forces. I suggest further research into the success with which the UN has applied its newly expanded norms in peacekeeping missions since making its normative changes. I believe a critical review of measurable variables such as deaths prevented and refugees resettled would further illustrate the importance of adapting practices to circumstances. Above all, I encourage both scholars and policy-makers to rigorously evaluate 
the institutionalized patterns of behaviour that are being employed in peacekeeping efforts, whether by international institutions or individual states, and to assess their efficacy against possible alternatives. Let each of the thousands of lives lost in Bosnia and beyond serve as motivation to hold powerful institutions accountable to nothing short of the needs of the present moment.

\section{References}

Bellamy, Alex J., and Paul Williams. 2004. "Introduction: Thinking Anew About Peace Operations.” International Peacekeeping 11, no. 1: 1-15.

Crossette, Barbara. 1999. "U.N. Details Its Failure to Stop '95 Bosnia Massacre.” The New York Times. Accessed 19 November 2018. https://www.nytimes. com/1999/11/16/world/un-details-its-failure-to-stop-95-bosnia-massacre.html.

Daalder, Ivo H. 2016. "Decision to Intervene: How the War in Bosnia Ended." Brookings. Accessed 19 November 2018. https://www.brookings.edu/articles/ decision-to-intervene-how-the-war-in-bosnia-ended/.

Finnemore, Martha, and Kathryn Sikkink. 1998. "International Norm Dynamics and Political Change." International Organization 52, no. 4: 887-917.

Kaufman, Joyce P. 1999. "NATO and the Former Yugoslavia: Crisis, Conflict and the Atlantic Alliance.” The Journal of Conflict Studies 19, no. 2: 1-18.

Laurence, Marion. 2018. "An 'Impartial' Force? Normative Ambiguity and Practice Change in UN Peace Operations." International Peacekeeping: $1-25$.

Rhoads, Emily Paddon. 2016. "Taking Sides in Peacekeeping: Impartiality and the Future of the United Nations." Oxford: Oxford University Press.

Steiner, Barry H. 2004. Collective Preventive Diplomacy: A Study in International Conflict Management. Albany: State University of New York Press.

Widmaier, Wesley W., and Luke Glanville. 2015. "The Benefits of Norm Ambiguity: Constructingthe Responsibility to Protect across Rwanda, Iraq and Libya." Contemporary Politics 21, no.4: 367-83. 